\title{
$\underline{\mathrm{O} J \mathrm{ED}}$
}

Volume 5, Issue 1 (2020), pp. 76-83

International Journal of

Multidisciplinary Perspectives in Higher Education

ISSN: 2474-2546 Print/ ISSN: 2474-2554 Online

https://ojed.org/jimphe

\section{Teaching and Learning for this Moment: How a Trauma-Informed Lens Can Guide Our Praxis}

\author{
Cinzia Pica-Smith \\ Christian Scannell \\ Assumption University, Worcester, Massachusetts, USA
}

\begin{abstract}
In this time of COVID-19, continued and relentless violence against Black, Indigenous, and People of Color, (BIPOC), organized resistance by many young people, and violent institutionalized attempts to suppress resistance, demonstrations and social change movements, what should educators be thinking about as we return to our college classrooms? In this short piece, we share our thinking and experience about our students' psycho-social needs and our belief that faculty must be focused both on students' and faculty's socio-political context and students' and faculty's emotional wellbeing as we think about teaching and learning for this moment.
\end{abstract}

Keywords: covid-19, critical conversations, critical pedagogy, higher education, pandemic, supportive environments, trauma-informed pedagogy

We are two faculty members in the Human Services (both of us trained and experienced counseling professionals and one of us currently a practicing psychotherapist). Over the past three months we have had extensive conversations with both students and colleagues which have sparked much thinking about our praxis and what frameworks may be helpful to think through teaching and learning in 
higher education during this tumultuous time of COVID-19, continued police violence against Black, Indigenous, and People of Color (BIPOC), organized resistance and social change work by youth activists, and the violent institutionalized attempts to suppress people demonstrating against systemic racism. As we move into the Fall 2020 semester our institutions are grappling with "transition plans" and modalities of teaching and learning. Our colleagues are beginning to talk about how to "deliver" instruction whether we will be online, in-person or teaching hybrid courses. Much attention is being paid to the content and method of instruction for these courses and faculty are having deep conversations about pedagogies and learning new technologies to accommodate for these possible new realities. In this short piece, we would like to turn our attention to our students' psycho-social needs and to our belief that faculty must be focused on students' socio-political context and students' emotional wellbeing as we think about teaching for this moment. This requires a balance between our primary mission of providing high-caliber education and the reality of what our students currently need to effectively engage in the learning process.

Our experiences as counselors informed in systemic theoretical frameworks (i.e. ecological systems theory, critical multicultural education, social justice education) and trauma-informed care have been helpful in planning meaningful classroom experiences to build psycho-social supportive environments. Our theoretical assumptions inform how we co-construct the classroom environment, the relationship-building that occurs between us, and how we go about structuring teaching and learning throughout the semester. Our students are engaged in the complex realities of our socio-political context and bring their experiences (often of intra and interpersonal and systemic crisis and trauma) into the classroom, and into their engagement with learning. We believe a Systems-informed paradigm and trauma-informed classroom practice should always guide educators and especially at this moment of national/international crisis.

During the Spring 2020 semester as the COVID-19 pandemic was exploding internationally and here in the United States, institutions of higher education where students lived and learned abruptly shifted to online instruction. With little time to prepare or adjust, students were asked to leave the spaces where they had been 
co-creating their community with friends and faculty and asked to "return home."

Once off campus, faculty amidst their own anxiety and stressors, were encouraged to reassure students that they would be provided with a "seamless" transition to resume their education, often with promises that it would continue to be as "rigorous" as it had been in the in-person setting. Conversations and debates amongst educators arose about how to support students during these chaotic and unpredictable times. After all, wouldn't creating routine, establishing a "new normal" and helping students get back into a groove help them?

However, students were not just negotiating the challenges of the new online learning environment. Students were not just learning how to engage in new remote education through flipped classrooms, seeing their instructors lecture through Zoom or YouTube or having their lectures asynchronously. Some became homeless almost overnight, others were facing the prospect of a suddenly uncertain job market, others experienced unemployment and food insecurity in their families and communities, caring for ill family members--and doing so within a larger struggling healthcare system. Our students were adding many household responsibilities to their already-complex lives without community infrastructure for support. We heard from students who were homeschooling their younger siblings and sharing their technology in the process. Others began to work full time as essential workers in pharmacies, nursing homes, and grocery stores. For those whose family members became ill, responsibilities of parenting and nursing their loved ones to health were added to their growing lists of demands. And, as family violence is ubiquitous, we were all too aware that our students, and students across the nation, often returned to homes where they experienced trauma and where "shelter in place" often meant something antithetical to safety.

As the spring semester came to an end, the ever-present systemic and institutionalized racism that exists in our country was brought to light, once again, in the latest in an interminable list of murders of Black people by police. And, once again, a video-taped murder caused both trauma and action on a massive scale. Young people organized and spoke out. Demonstrations ensued and paramilitary response and violence followed. BIPOC students spoke about their trauma and how difficult it would be to focus, concentrate 
and study in this context of violence against BIPOC. Their concerns for the fall semester rang loudly and clearly.

Given this socio-political context, the emotional consequences on our students (and ourselves), and our motivation to be more effective in the classroom, we found ourselves asking how we could develop a path forward that recognizes and adjusts our praxis to integrate psychological supports and a trauma-informed approach.

While the current times present challenges for educators, we propose taking a purposeful approach to our interactions with students and colleagues in and out of the classroom to foster an appreciation of the existence of invisible trauma and intersectionality (Sweeny et al., 2018) that will build resilience and support student success. This process can begin with asking ourselves what our students need now and what we may need to do to support them in this critical context? We need to find effective ways to recognize and deal with unfamiliar dynamics in the classroom, even when this creates discomfort, to create safe spaces for students to share their reactions and emotions (Clair et al., 2002), and to build competency in talking about race and racism (Fox, 2009; Kernahan, 2019; Sue, 2015; Tatum, 2003).

While adversity is a predictable part of the human experience, its impact on functioning and responses are varied requiring a personcentric approach to support and interventions (Bohannon et al., 2019; Bonnano, 2004). It will be important not to make assumptions about how students are responding to events; rather, it will be important to ask how they are impacted. We must also recognize the direct influence of contextual factors on resilience, making our role critical to adaptation and capacity building (Crosby, 2015; Noltemeyer \& Bush, 2013). To assist in the process of functional adaptation to the uncertain landscape ahead, we propose that educators consider the following suggestions.

1) Recognize that students cannot decontextualize their learning from their social identities or the sociopolitical context. We are reminded hundreds of times per day that we are amidst a global pandemic and in a historical moment of reckoning with white supremacy and racism. These realities will need to be acknowledged and brought forth into the spaces we create in our classrooms (Bozkurt \& Sharma, 2020; Watermeyer et al., 2020).

2) Find ways to authentically connect with each student and have a willingness to be vulnerable. In times of crisis, educators find themselves in the role of responder to students' who are experiencing a crisis; however, this is a salient moment to shift this 
to an acknowledgement of shared experiences and to set the tone for vulnerability, honesty, humility and openness (Bozkurt \& Sharma, 2020; Clair et al., 2002). The ability to recognize shared lived experiences can directly influence coping and emotional regulation while allowing for learning to be positioned as a dialogue among equals. This dynamic is very empowering giving student's ownership of the process and outcome of learning. Further, social distancing guidelines can directly undermine the supports that our students need and their perception of what they are returning to in the coming semesters. We can assist in enhancing connectedness by taking steps to learn students' names, understanding who they are in the context of their lives and learning the strengths that they are bringing to our classrooms.

3) Be prepared to play multiple roles and to be flexible. While current research shows that educators found themselves reducing the expectations that they had for students in the Spring of 2020, this also created dialogue about how to balance rigor while providing critical skill acquisition and opportunities for practice and demonstration (Ralph, 2020; Watermeyer et al., 2020). Although learning is the primary goal of the college experience, supporting students' social-emotional health and helping them process these unprecedented events is necessary to achieve it (Bozkurt \& Sharma, 2020; Morgan et al., 2015). This is not to suggest that we abandon our roles of expert educators to become mental health practitioners, but it does foster the need to look at ways to creatively adapt to the current situation and its ever-changing trajectory, which may include flexibility in scheduling, reaching out to students who have fallen behind, and employing crisis-intervention skills with compassion and sensitivity. Shifting the educator role to include one of resource broker will include providing avenues to access social, physical, and emotional support. Rather than seeking to lower the bar for student achievement, we can foster success by meeting students where they are and devising a plan to move forward.

4) Be clear and consistent in our expectations and communication. Miscommunication and confusion of expectations can increase the stress experienced by our students (Sahu, 2020). While we now exist in a world where Zoom has become our home office and classrooms and we are regularly seeking innovative ways to improve our curricula, perhaps of greater importance is consistency in routine and expectations when designing our course expectations. Research on flipped classrooms and blended learning models has shown benefits to students including increased skills such as independent problem solving (Suebsom, 2020), increased selfefficacy and intrinsic motivation (Thai et al., 2017). In addition, 
students have reported higher rates of satisfaction and feelings of competence (Sergis et al., 2018). However, in order for these outcomes to come to fruition, we must first recognize that not all of our students have had the same exposure to these pedagogies, innovative technologies and terminology as we have. We have spent endless hours researching practicing and preparing for a classroom environment that may look very different from what our learners may have expected. This makes course orientation, practice, clear communication, and consistency more critical than ever before. We should not make assumptions about our students' prior knowledge and familiarity with online pedagogy and instead patiently introduce and reintroduce them to the online, blended, hybrid, HiFlex, synchrounous, asynchrounous learning to ensure their understanding and informed participation in the classroom. This, in turn, will result in decreased confusion and increased participation and success.

While this moment presents challenges to our teaching and learning, we believe there are ways in which we can co-construct meaningful classroom communities (whether online or in-person) where both students and faculty may thrive. In order to do this, however, it will be important to focus on students' psycho-social wellbeing, being ever-mindful that the sociopolitical context and students' and faculty's social identities enter the classroom and the learning space. When faculty can be vulnerable and share their lived experience, get to know their students and create connections with them, bring the outside world and acknowledge the realities of the moment into the classroom, approach difficult conversations, connect students with appropriate supports when needed, and communicate clear and consistent expectations they will be creating safe and supportive communities where students and faculty can learn and thrive.

\section{References}

Bohannon, L., Clapsaddle, S., \& McCollum, D. (2019). Responding to College Students Who Exhibit Adverse Manifestations of Stress and Trauma in the College Classroom. FIRE: Forum for International Research in Education, 5(2), 66-78.

Bonanno, G. A. (2004). Loss, trauma, and human resilience: Have we underestimated the human capacity to thrive after extremely aversive events? American Psychologist, 59(1), 20-28. https://doi.org/ 10.1037/0003-066X.59.1.20

Bozhurt, A. \& Sharma, R. C. (2020). Emergency remote teaching in a time of global crisis due to CoronaVirus pandemic. Asian Journal of 
Distance

Education,

i-vi.

https://doi.org/10.5281/zenodo.3778083

Crosby, S. D. (2015). An Ecological Perspective on Emerging Trauma-Informed Teaching Practices. Children \& Schools, 37(4), 223-230. https://doi.org/10.1093/cs/cdv027

Clair, J. A., Maclean, T. L., \& Greenberg, D. N. (2002). Teaching through traumatic events: Uncovering the choices of management educators as they responded to September 11th. Academy of Management Learning \& Education, 1(1), 38-54. https://doi.org/10.5465/AMLE.2002.7373603

Fox, H. (2009). "When race breaks out:" Conversations about race and racism in college classrooms. Peter Lang.

Kernahan, C. (2019). Teaching about race and racism in the college classroom: Notes from a white professor. West Virginia Press.

Morgan, A., Pendergast, D., Brown, R., \& Heck, D. (n.d.). Relational ways of being an educator: trauma-informed practice supporting disenfranchised young people. International Journal of Inclusive Education, 19(10), 1037-1051. https://doiorg /10.1080/13603116.2015.1035344

Ralph, N. (2020). Bay View Analytics.

http://onlinelearningsurvey.com/covid.html.

Sahu P. (2020). Closure of Universities Due to Coronavirus Disease 2019 (COVID-19): Impact on Education and Mental Health of Students and Academic Staff. Cureus, 12(4), e7541. https://doi.org/10.7759/cureus.7541

Sergis, S., Sampson, D. G., \& Pelliccione, L. (2018). Investigating the impact of Flipped Classroom on students' learning experiences: A Self-Determination Theory approach. Computers in Human Behavior, 78, 368-378. https://doi.org/10.1016/j.chb.2017.08.011

Sue, D. W. (2015). Race talk and the conspiracy of silence. Wiley.

Suebsom, K. (2020). The Use of Blended Learning: Social Media and Flipped Classroom to Encourage Thinking Skills and Collaborate Work in Higher Education. Proceedings of the 2020 the 3rd International Conference on Computers in Management and Business, 201-206. https://doi.org/10.1145/3383845.3383883

Sweeney, A., Filson, B., Kennedy, A., Collinson, L., \& Gillard, S. (2018). A paradigm shift: relationships in trauma-informed 
mental health services. BJ Psych advances, 24(5), 319-333. https://doi.org/10.1192/bja.2018.29

Tatum, B. D. (2003). Talking about race, learning about racism: The application of Racial Identity Development Theory in the classroom. In A. Howell \& F. Tuitt (Eds.) Race and higher education: Rethinking pedagogy in diverse college classrooms (pp. 139-163). Harvard Educational Review.

Thai, N. T. T., De Wever, B., \& Valcke, M. (2017). The impact of a flipped classroom design on learning performance in higher education: Looking for the best "blend" of lectures and guiding questions with feedback. Computers \& Education, 107, 113-126. https://doi.org/10.1016/j.compedu.2017.01.003

Watermeyer, R., Crick, T., Knight, C., \& Goodall, J. (2020). COVID19 and digital disruption in UK universities: Afflictions and affordances of emergency online migration. Higher Education. https://doi.org/10.1007/s10734-020-00561-y

\section{Author Bios}

CINZIA PICA-SMITH, Ed.D. is an Associate Professor in the Department of Human Services and Rehabilitation Studies at Assumption University where she also teaches in the Women's Studies Program. She has focused her research on youth's experiences in schools paying particular attention to how educators and school systems in both the U.S. and Europe can create equitable and socially just school environments to support young people. She focused on cross-race friendships among youth in a recent TEDx talk. Email: cpicasmith@assumption.edu

CHRISTIAN SCANNELL, M.S., M.A, is a Professor of Practice in the Department of Human Services and Rehabilitation Studies at Assumption University where she is also the Coordinator of the Concentration, Working with Children and Adolescents in Community Settings. She is a licensed and practicing psychotherapist who has 18 years of experience working with individuals, families, and children in the areas of trauma, resilience, grief, and substance abuse. She has focused her research on the experience of adversity including peer and social supports, disenfranchised grief, selfefficacy, and posttraumatic growth. 